\title{
PENYELENGGARAAN PENDIDIKAN AGAMA DI UNIVERSITAS PATTIMURA AMBON
}

\author{
MANAGING RELIGIOUS EDUCATION \\ IN PATTIMURA UNIVERSITY AMBON
}

\author{
Hayadin \\ Puslitbang Pendidikan Agama dan Keagamaan \\ Jl. MH Thamrin no. 6, Jakarta Pusat. \\ Email: hayadin006@gmail.com
}

Naskah diterima 10 Oktober 2016, direvisi 30 Oktober 2016, disetujui 5 November 2016

\begin{abstract}
This article aims to explain the implementation of religious education at the University of Pattimura Ambon. There are include: the curriculum, the learning process, facility / facilities, learning resources and evaluation. The study was conducted using a qualitative approach. Source of data derived from the leaders of the university, leacturers of religious education, leaders of student organizations, and students. There were using interview as the way those data collected. Data and information was also obtained through observation and document study. The research results show that position of religious education subject at the University of Pattimura still being under the General Basic Course, neither under the Public Mandatory Subject nor under the Personality Development Subject. The curriculum was derived from modules developed by lecturers with reference to a national standard book. The religious education means and infrastructures were still very lessen. Even, the leacturers of religious education didn't have an office or room for working on campus. They were only present to teach and then go home after performing the lesson. The lecturers of Islamic religious education got supporting from the Campus Missionary Agencies (kind of Islamic students organisation within campus), both in the lecture as well as in other religious activities.
\end{abstract}

Keywords: religious lecturer, religious education, Pattimura University.

\begin{abstract}
Abstrak
Tulisan ini bertujuan untuk menjelaskan penyelenggaraan pendidikan agama di Universitas Pattimura Ambon, yang meliputi: kurikulum, proses pembelajaran, sarana/fasilitas pembelajaran, sumber belajar dan evaluasi belajar. Penelitian dilakukan menggunakan pendekatan kualitatif. Sumber data diperoleh dari pimpinan perguruan tinggi, dosen pendidikan agama, pimpinan organisasi mahasiswa, dan mahasiswa, dengan menggunakan teknik wawancara. Data dan informasi juga diperoleh melalui observasi dan studi dokumen. Hasil penelitian menunjukan bahwa posisi pembelajaran pendidikan agama di universitas Pattimura masih menjadi bagian dari kelompok Matakuliah Dasar Umum, bukan Pengembangan Kepribadian atau Wajib Umum. Kurikulum berasal dari modul yang dikembangkan oleh para dosen dengan merujuk pada buku standar. Sarana prasarana pembelajaran pendidikan agama masih sangat minim. Para dosen pendidikan agama tidak memiliki ruangan untuk kantor dan bekerja di kampus. Mereka hanya hadir untuk mengajar lalu pulang. Dosen pendidikan agama Islam banyak mendapat bantuan dari lembaga dakwah kampus, baik dalam proses perkuliahan maupun dalam aktivitas keagamaan lainnya.
\end{abstract}

Kata kunci: Dosen Agama, Pendidikan Agama, Universitas Pattimura 


\section{PENDAHULUAN}

Mengetahui bagaimana penyelenggaraan pendidikan agama di perguruan tinggi sangat bermanfaat dalam rangka menempatkan posisi perguruan tinggi pada perannya sebagai agent os social change. Melalui pendidikan agama maka berbagai disiplin ilmu sekuler yang dipelajari dapat terwarnai atau dibalut dengan nilai-nilai etis dan moral. Religious education is important because it equips students with cultural, social, moral and spiritual knowledge that aids in mental and physical development within society. Religious education assists students in forming values and beliefs that are reflected in behaviors and communication. ${ }^{1}$

Pendidikan tinggi berfungsi menghasilkan intelektual, ilmuwan, dan/ atau profesional yang berbudaya dan kreatif, toleran, demokratis, berkarakter tangguh, serta berani membela kebenaran untuk kepentingan bangsa. ${ }^{2}$ Karena fungsi tersebut maka eksistensi dan aktivitasnya menjadi sangat menentukan keberadaan dan masa depan suatu bangsa atau suatu daerah. Perguruan tinggi yang baik akan menjadi pusat atau simpul bagi daerah atau negara untuk m enjadi baik. Melalui alumni dan sivitas akademikanya, perguruan tinggi dapat mengimoplementasikan nilai-nilai baiknya di masyarakat.

Keberadaan universitas Patimura sebagai perguruan tinggi pertama dan berstatus negeri di provinsi Maluku menjadi salah satu institusi yang telah melahirkan

${ }^{1}$ https://www.reference.com/world-view/ religious-education-important-aa58f6bbce7b79e0, dikutip: 6 Septembert 2016.

${ }^{2}$ Undang-undang nomor 12 tahun 2012, tentang Pendidikan Tinggi. sejumlah ilmuwan, dan intelektual yang berpengaruh dalam level nasional ataupun dalam level daerah. Di universitas ini berbagai suku dan bahasa hadir dengan tujuan yang sama untuk menuntut ilmu pengetahuan untuk tujuan yang luhur. Heterogenitas warga belajar dan sivitas akademika menjadi hal yang wajar terjadi pada berbagai kampus.

Kini di Maluku, khususnya di kota Ambon pasca konflik, terjadi segregasi sosial antar umat beragama. Pemukiman wilayah utara mayoritas dihuni oleh warga muslim, sementara pemukiman wilayah selatan banyak dihuni oleh warga Kristen. ${ }^{3}$ Segregasi tersebut merupakan hasil dari konflik dan sebagai konsekwensi dari pluralitas masyarakat Ambon. Plural-Segregatif, kini menjadi predikat kota Ambon, dan provinsi Maluku pada umumnya. ${ }^{4}$

Gambaran kontemporer masyarakat Ambon tersebut, menjadi tantangan tersendiri bagi universitas Pattimura, dan bagi sivitas akademiknya. Mahasiswa dan dosen sebagai sumber daya manusia kampus menjadi tulang punggung utama memecahkan masalah tersebut. Mata kuliah pendidikan agama, dapat menjadi salah satu untuk utama bahkan dapat menjadi dasar bagi mata kuliah politik, budaya dan kewarganegaraan, dalam menanamkan dan membentuk wawasan, sikap dan perilaku yang terpuji kepada mahasiswa untuk menjadi agen perekat sosial di kota Ambon.

\footnotetext{
${ }^{3}$ Yunus Rahawarin, 2013. Kerja sama antar umat beragama: Studi Rekonsiliasi Konflik Agama di Maluku dan Tual. Vol. VII, nomor 1. h. 97

${ }^{4}$ Eddy O.S. Hieriej, ed., Format Ulang Birokrasi kota Ambon. h. 15: http://www.batukarinfo.com/system/ files/Ambon\%20SKJ\%20Lengkap.pdf, dikutip pada 5 September 2016.
} 
Selain gambaran tersebut, pada sisi lain, eksistensi mata kuliah pendidikan agama di perguruan tinggi mengalami dinamika tersendiri yang komplek. Kompleksitas tersebut terkait dengan status otonomi pengembangan ilmu pengetahuan di perguruan tinggi, dan birokrasi pendidikan sentralistik, yang dipegang oleh menteri pendidikan. Dalam undang-undang pendidikan tinggi dinyatakan bahwa "Dalam penyelenggaraan Pendidikan dan pengembangan Ilmu Pengetahuan dan Teknologi berlaku kebebasan akademik, kebebasan mimbar akademik, dan otonomi keilmuan. ${ }^{5}$ Otonomi Perguruan Tinggi adalah kemandirian dalam pengelolaan Perguruan Tinggi yang dilaksanakan sesuai dengan kemampuan Perguruan Tinggi untuk mencapai tujuan sesuai dengan visi dan misi Perguruan Tinggi. ${ }^{6}$

Secara otonom di bidang ilmu pengetahuandanteknologi,setiap perguruan tinggimemiliki hakuntuk merumuskan arah, tujuan, materi dan strategi pembelajaran di lingkungan kamusnya. Pada sisi lain, menteri pendidikan atau pemerintah pusat memiliki kewenangan juga untuk mengatur perguruan tinggi yang ada di Indonesia dalam rangka mencapai tijuan pendidikan nasional.

Dalam konteks mata kuliah pendidikan agama, universitas Patimura memiliki hak secara otonom untuk mengembangkan

\footnotetext{
${ }^{5}$ Op.cit, Undang-undang nomor 12, pasal 8.

${ }^{6}$ Novitasari, Suko Wiyono. Penerapan Otonomi Perguruan Tinggi Untuk Menunjang Pelaksanaan Tridharma Di Jurusan Hukum Dan Kewarganegaraan Fakultas Ilmu Sosial Universitas Negeri Malang, h. 1: http://jurnal online.um.ac.id/data/artikel/artike 185CB89239345E974CBDF4A662733E490.pdf, dikutip pada tanggal 5 September 2016.
}

pembelajaran yang mendukiung visi, misi, dan tujuan universitas. Termasuk juga menjawab tantangan dan masalah regional di wilayah maluku dan sekitarnya. Secara ideal diharapkan dengan adanya perkuliahan pendidikan agama, maka seluruh disiplin ilmu, penetauhan dan ketrampilan akademik mahasiswa mendapatkan spirit dan landasan nilai religius. Oleh karena itu, pada tahap awal menjadi menarik untuk meneliti proses penyelenggaraan pendidikan agama di Universitas Pattimura.

Rumusan masalah penelitian adalah sebagai berikut: Bagaimana proses penyelenggaraan mata kuliah agama Islam di Universitas Pattimura, dilihat dari aspek: kurikulum, sistem pembelajaran, sarana/ fasilitas, sumber belajar dan evaluasi belajar. Adapaun tujuan penelitian adalah untuk mengetahui proses penyelenggaraan pendidikan mata kuliah agama di universitas Pattimura pada aspek: kurikulum, proses pembelajaran, sarana/fasilitas, sumber belajar dan evaluasi belajar.

\section{Kerangka Konseptual}

\section{Sistem Pendidikan Agama}

Dalam sistem pendidikan nasional, pendidikan agama merupakan salah satu kewajiban yang harus diselenggarakan oleh setiap lembaga pendidikan agama baik swasta ataupun negeri, mulai dari jenjang pendidikan dasar hingga pendidikan tinggi. ${ }^{7}$ Kewajiban yang bersifat konstitusional tersebut sebagai implementasi dari sila pertama pancasila, "Ketuhanan Yang Maha Esa" yang menunjukkan bahwa

${ }^{7}$ UU nomor 2 tahun 1989, dan UU nomor 20 tahun 2003, tentang Sistem Pendidikan Nasional. 
nilai-nilai religius atau agama menjadi landasan utama dalam aktivitas seharihari warga negara, baik terkait dengan kehidupan bermasyarakat, berbangsa ataupun bernegara. Pemberian materi pelajaran agama kepada setiap peserta didik diharapkan agar supaya pengetahuan, sikap dan perilaku beragama setiap warga negara senantiasa terpelihara dan berkontribusi terhadap kelestarian dan kemajuan bangsa sebagaimana amanat pendiri bangsa.

Jika merujuk pada sistem pendidikan nasional, maka pendidikan nasional berfungsi mengembangkan kemampuan dan membentuk watak serta peradaban bangsa yang bermartabat dalam rangka mencerdaskan kehidupan bangsa, bertujuan untuk berkembangnya potensi peserta didik agar menjadi manusia yang beriman dan bertakwa kepada Tuhan Yang Maha Esa, berakhlak mulia, sehat, berilmu, cakap, kreatif, mandiri, dan menjadi warga negara yang demokratis serta bertanggung jawab. ${ }^{8}$ Definisi yang dikembangkan juga menyatakan bahwa pendidikan adalah usaha sadar dan terencana untuk mewujudkan suasana belajar dan proses pembelajaran agar peserta didik secara aktif mengembangkan potensi dirinya untuk memiliki kekuatan spiritual keagamaan....,.9 selanjutnya fungsi dari pendidikan agama adalah membentuk manusia Indonesia yang beriman bertakwa kepada Tuhan Yang Maha Esa, serta berakhlak mulia dan mampu menjaga kedamaian dan kerukunan hubungan inter dan antar umat beragama. Pendidikan agama bertujuan

8 UU nomor 20 tahun 2003, tentang Sistem Pendidikan Nasional, pasal, 3.

${ }^{9}$ Ibid., pasal, 1. untuk berkembangnya kemampuan peserta didik dalam memahami, menghayati, dan mengamalkan nilai nilai agama yang menyerasikan penguasaannya dalam pengembangan ilmu pengetahuan, seni dan teknologi. ${ }^{10}$

Pelaksanaan pembelajaran mata kuliah Pendidikan Agama di perguruan tinggi mengalami pasang surut. Pada awal tahun 1960-an, pendidikan agama merupakan mata kuliah umum yang tidak mengikat karena hanya sebagai mata kuliah 'anjuran'. Kemudian pada masa orde baru pendidikan agama mengalami 'penguatan' pada saat matakuliahagama menjadimatakuliah wajib yang diberikan kepada setiap mahasiswa dan dikelola oleh sebuah Biro Mata Kuliah Pendidikan Agama sebagaimana mata kuliah wajib lainnya, misalnya, Pendidikan Pancasila, Pendidikan Kewiraan, Pendidikan Kewarganegaraan, Pendidikan Bahasa Indonesia dan lain-lain. Sesuai dengan pesan kurikulum tahun 1983, pengelolaan mata kuliah wajib ini berubah dari biro menjadi Jurusan Mata Kuliah Dasar Umum (MKDU) di bawah fakultas yang terdekat dengan bidang keilmuannya. Penamaan MKDU memiliki dasar filosofis yang jelas karena mata kuliah yang tergabung dalam MKDU sebagai fundamen yang memberikan landasan spiritual keagamaan, moral, kebangsaan, nasionalisme, dan sosial budaya dalam mengembangkan bidang ilmu dan keahliannya masing-masing.

Pada tahun 1990 nama MKDU berubah menjadi MKU (Mata Kuliah Umum), dan pada tahun 2000 berubah lagi menjadi MPK (Mata Kuliah Pengembangan Kepribadian).

${ }^{10}$ PP nomor 55 tahun 2007, tentang Pendidikan Agama dan Keagamaan, pasal 2 ayat $1-2$. 
Perubahan nama kelompok mata kuliah wajib ini diikuti perubahan kelembagaan dan pengelolaannya. Semula kelembagaan MKD berkedudukan setingkat jurusan (Jurusan MKDU) dan berada di bawah fakultas tertentu yang paling dekat dengan bidang keilmuannya. Kemudian, MKDU berubah menjadi sebuah Unit Pelaksana Teknis Mata Kuliah Umum (UPT-MKU) di bawah koordinasi langsung Pembantu Rektor 1 bidang akademik sampai saat ini. ${ }^{11}$ Kini mata kuliah pendidikan agama berubah lagi menjadi kelompok Mata Kuliah Wajib Umum (MKWU), berdasarkan UU Pendidikan Tinggi nomor 12 tahun 2012.

Beberapa penelitian terpublikasi yang relevan antara lain ditulis oleh: Abdul Munip, Imran Siregar, Mardiono, Lilik Nur Kholidah. Tulisan Abdul Munip berjudul "Perkuliahan pendidikan agama Islam di perguruan tinggi negeri (sebuah catatan lapangan), membahas tentang sistem penyelenggaraan pendidikan agama Islam di sejumlah perguruan tinggi negeri (PTN) yakni: Universitas Negeri Medan (UNIMED), Universitas Andalas (UNDALAS), Universitas Indonesia (UI), Institut Pertanian Bogor (IPB), Institut Teknologi Bandung (ITB), Universitas Gadjah Mada (UGM), Universitas Negeri Semarang (UNNES), Universitas Brawijaya (UNIBRAW), Institut Teknologi Sepuluh Nopember (ITS), Universitas Negeri Jember (UNEJ), Universitas Lambung Mangkurat (UNLAM), Universitas Hasanuddin (UNHAS), dan Universitas

\footnotetext{
${ }^{11}$ Panduan pembelajaranPendidikanagama Islam (PAI) di Perguruan Tinggi, http://kuliahdaring.dikti. go.id/lms1/pluginfile.php/14028/mod_resource/ content/4/PANDUAN\%20PEMBELAJARAN\%20PAI. pdf, dikutip pada tanggal 5 September 2016
}

Mataram (UNRAM). ${ }^{12}$ Perguruan tinggi tersebut diatas telah menyelenggarakan pendidikan agama berdasarkan SK Dirjen Dikti Depdiknas No: 43/DIKTI/Kep/2006 tentang Rambu-Rambu Pelaksanaan Kelompok Matakuliah Pengembangan Kepribadian di Perguruan Tinggi.

Imran Siregar, menulis hasil penelitian berujudul 'Model Pengajaran Agama Islam di Universitas Sumatera Utara (USU) Medan. ${ }^{13}$ Dalam prakteknya Aktivitas poembelajran dosen PAI dikordinir oleh LIDA. Meskipun realitasnya LIDA tidak maksimal dapat mengkordinir para dosen PAI khususnya yang berstatus swasta atau honorer. Dosen PAI lebih menitikberatkan pada aspek kognitif, sehingga mahasiswa mencari alternatif pembelajaran dari luar (sebagai kompetitor desen PAI). Materi pengajaran PAI terbagi menjadi dua kelompok materi, yaitu materi pokok yang sesuai dengan GBPP dan materi yang disesuaikan dengan kompetensi dan disiplin ilmu masingmasing fakultas dan jurusan/program studi.

Penelitian Murdiono menemukan bahwa internalisasi nilai moral religius tidak hanya dilakukan oleh dosen pengampu mata kuliah agama, tapi juga bisa dilakukan oleh semua dosen mata kuliah. ${ }^{14}$ Lilik Nur Kholidah, menguatkan apa yang diteliti oleh

12 Abdul Munip. 2008. Perkuliahan pendidikan agama Islam di perguruan tinggi negeri (sebuah catatan lapangan), Jurnal Pendidikan Agama Islam Vol. V, No, 1,2008: http://digilib.uin-suka.ac.id/8757/..., dikutip pada 5 September 2016.

${ }^{13}$ Imran Siregar, 2014. Model Pengajaran Agama Islam Di Universitas Sumatera Utara (USU) Medan, Jurnal AL-Qalam, Makassar, vol. 20. Nomor 1.

14 Mukhammad Murdiono, tanpa tahun. Strategi Internalisasi Nilai Moral Religius Dalam Proses Pembelajaran di Perguruan Tinggi, Jurnal Cakrawal Pendidikan, LPM UNY. 
Murdiono bahwa diantara keberhasilan para dosen dalam penyampaikan mata kuliah pendidikan agama Islam karena faktor materi belajar dan media pembelajaran yang cukup memadai, dan sangat membantu tercapainya tujuan pembelajaran. Dalam proses pengajaran, dosen tidak hanya sekedar melakukan transfer pengetahuan, tapi juga melakukan kontrol terhadap proses belajar dan mengerjakan tugas belajar, pendampingan secara individual dalam proses pembelajaran secara langsung. Ada faktor internal dan faktor eksternal yang mempengaruhi keberhasilan proses pendidikan mata kuliah agama. Secara internal, kapasitas dosen dari segi kemampuan mengajar, tingkat pengetahuan, penggunaan media belajar. Dari mahasiswa, faktor motivasi sangat berpengaruh terhadap minat belajar mahasiswa. Secara eksternal, visi misi PT, kurikulum yang digunakan dan tujuan pembelajaran yang lebih mengedepankan aspek afektif dan attitude mahasiswa ${ }^{15}$.

\section{METODOLOGI PENELITIAN}

Jenis penelitian ini adalah studi kasus (case study) dengan pendekatan paradigma kualitatif. Dari segi manfaatnya, penelitian ini merupakan penelitian kebijakan, yakni pengelolaan pendidikan di perguruan tinggi. Oleh karena itu, maka landasan konsep yang digunakan adalah kebijakan pemerintah di bidang pendidikan agama dan perguruan yang tinggi. Penelitian ini dilakukan di Universitas Patimura Ambon,

${ }^{15}$ Lilik Nur Kholidah, 2010. Implementasi strategi pembelajaran mata kuliah pendidikan agama Islam pada Perguruan Tinggi Negeri di Surabaya, Disertasi, Universitas Negeri Malang.
Maluku, pada bulan Mei hingga Oktober tahun 2012. Teknik pengumpulan data meliputi wawancara terstruktur, wawancara mendalam (indepth interview), pengisian kuesioner, studi dokumen dan observasi.

Beberapa responden dan informan yang dijangkau antara lain: pimpinan Universitas Pattimura (PR III), dosen pendidikan agama, organisasi mahasiswa, dan aktivis kampus. Selanjutnya, data dan informasi yang diperoleh diolah secara deskriptif, dan komparatif. Deskrisi dilakukan terhadap data primier yang diperoleh di lapangan. Dan analisi komparatif dilakukan terhadap data sekunder dan data relevan terhadsap kasus serupa yang diperoleh dari publikasi peneliti lainnya yang serupa. Setelah penulisan laporan lapangan, kemudian dilakukan pendalaman dan triangulasi ke lokasi penelitian untuk memperkuat keterpercayaan dan keabsahan data dan informasi yang diperoleh.

\section{HASIL DAN PEMBAHASAN}

\section{Sejarah dan Konteks Sosial Universitas Pattimura}

Universitas Pattimura disingkap UNPATTI adalah salah satu Perguruan Tinggi Negeri yang terletak di Provinsi Maluku, tepatnya di jalan Ir. M. Putuhena, Poka, kota Ambon. Sejarahnya bermula ketika beberapa tokoh masyarakat mengambil prakarsa untuk mendirikan suatu lembaga Pendidikan Tinggi di Maluku yang dimulai oleh seorang tokoh pendidikan yaitu Dr. J. B. Sitanala (almarhum). Visi universitas adalah menjadi universitas yang unggul dan kompetitif dalam pengembangan sumberdaya manusia, ilmu pengetahuan, teknologi dan 
seni (ipteks) berbasis kepulauan. ${ }^{16}$ Misinya adalah: Meningkatkan kapasitas tampung dan akses pelayanan secara berkelanjutan; Menghasilkan lulusan yang berkualitas dan kompetensi dalam persaingan pasar global; Meningkatkan kualitas prasarana dan sarana pendidikan secara berkelanjutan; Meningkatkan kualitas lembaga dalam pendidikan, penelitian dan pengabdian kepada masyarakat; Meningkatkan Tata kekola, akuntabilitas dan pencitraan publik. ${ }^{17}$

Pegawai UNPATTI, mayoritas berlatar belakang agama Nasrani. ${ }^{18}$ Hingga 26 Juli 2013, jumlah dosen muslim di Unpatti yang terdata sebanyak 165 orang dari keseluruhan dosen Unpatti yang kurang lebih 2000an. Data mahasiswa Universitas Pattimura (UNPATTI) tahun 2009-2012, adalah 24.000 orang. Dari jumlah tersebut terdapat 6353 orang mahasiswa muslim. Secara keseluruhan (termasuk mahasiswa angkatan dibawah 2009), mahasiswa muslim Unpatti sebanyak 9353. Prosentase jumlah mahasiswa muslim kurang lebih 40\%; sementara mahasiswa Kristen kurang lebih di angka $57 \%$. Sedangkan sisanya sebanyak $3 \%$ berasal dari mahasiswa agama-agama lain seperti Buddha, Hindu, dan Konguchu. ${ }^{19}$

Tercatat pada Juli 2013, jumlah dosen pendidikan agama Islam di Universitas Pattimura berjumlah 7 orang, dengan perincian sebagai berikut: 1). Rahmawati

\footnotetext{
${ }^{16}$ http://www.unpatti.com/visi_misi_unpatti_ ambon.html, dikutip pada tanggal 8 oktober 2013.

${ }^{17}$.http://www.unpatti.com/visi_misi_unpatti_ ambon.html, dikutip pada tanggal 8 oktober 2013.

${ }^{18}$.Wawancara, Adriani Banjar, Pembantu Rektor 3, Ambon, 24 Juli 2013.

${ }^{19}$ Buku Profil Akademik Universitas Pattimura, Ambon, 2011.
}

Suat, MA; 2). Amin Ramly, MA; 3). Atikah Kharunnisa, MA;4). La Ode Angga, M.Hum; 5). Dr. Yunus Rahawaren, MA; 6). Drs. Ahmhad Kaplale: 7). Ode Abdur Rahman, MA. Akan tetapi, dari jumlah tersebut, dua sedang tidak aktif, yang pertama Drs. Ahmad Kaplale, sudah pensius, sementara La Ode Angga, M.Hum sedang menempuh pendidikan. ${ }^{20}$ Dengan demikian, dosen pendidikan agama Islam yang aktif mengajar saat ini hanya berjumlah lima orang. Mereka berasal dari wilayah dan etnis yang cukup beragam, Yakni Ambon, Boton, Jawa, Sulawesi, Betawi. Mereka juga berasal dari berbagai perguruan tinggi keagamaan dalam dan luar negeri. ${ }^{21}$

Dilihat dari latar belakang organisasi kemahasiswaan yang pernah mereka ikuti di saat menempuh pendidikan tingkat sarjana, sebagian besar adalah mantan aktivis organisasi kemahasiswaan Islam yang relatif populer di Indonesia, yakni mantan aktivis Pergerakan Mahasiswa Islam Indonesia (PMII); aktivis Ikatan Mahasiswa Muhammadiyah (IMM) dan Himpunan Mahasiswa Islam (HMI). ${ }^{22}$ Mereka masih konsisten dengan organisasi masingmasing ketika mereka lulus dari tingkat sarjana. ${ }^{23}$ Kendati secara organisasi sosial keagamaan hampir semua dosen pendidikan agama Islam UPATTI berafiliasi ke NU dan Muhammadiyah, tetapi aspirasi partai politik mereka juga belum tentu pada partai politik yang berbasis massa NU semisal

${ }^{20}$ Para Dosen Pendidikan Agama Islam UNPATTI: Amin Ramly, Rahmawati Suat, Yunus Rahawaring. Wawancara, Ambon, Juli 2013.

${ }^{21}$ Wawancara, Yunus Rahawaring, Kordinator Dosen PAI, Unpatti. Ambon, 22 Juli 2013.

${ }^{22}$ Wawancara, Abdul Kahar. Ambon, 23 Juli 2013.

${ }^{23}$ Wawancara, Yunus Rahawaring, Rahmawati Suat, Amin Ramly. Ambon, 21, 22, 25 Juli 2013. 
Partai Kebangkitan Bangsa (PKB) maupun berbasis Muhammadiyah seperti Partai Amanat Nasional (PAN). ${ }^{24}$

\section{Kedudukan Mata Kuliah Pendidikan Agama Islam}

Bila merujuk pada SK Mendiknas No. 232/U/2000 dan No.45/U/2002, mata kuliah pendidikan agama di perguruan tinggi umum seperti di Universitas Pattimura, tidak termasuk dalam materi yang berdiri sendiri, namun dimasukkan ke dalam materi Mata Kuliah Pengembangan Kepribadian atau lebih dikenal dengan MPK. ${ }^{25}$ Tujuan dari kebijakan tersebut untuk menjadikan pendidikan agama tidak semata-mata sebagai sumber pengetahuan, tetapi lebih dari itu, untuk menjadikan agama sebagai sumber etik dan etos dalam membentuk manusia yang beriman dan bertakwa. ${ }^{26}$ Akan tetapi kebijakan Mendiknas dengan menjadikan pendidikan agama sebagai MPK yang tidak berdiri sendiri itu belum diimplementasikan di UNPATTI. Sistem dan model pembelajaran pendidikan agama Islam di Universitas Pattimura masih menggunakan sistem lama dalam bentuk mata kuliah umum yang berdiri sendiri dan berada di bawah payung atau koordinasi MKU (mata kuliah umum). Seperti pola-pola sebelumnya, MKU ini membawahi kurang lebih empat mata kuliah: Civic Education

${ }^{24}$ Wawancara, Abdul Kahar, Atikah Kharunnisa, Yunus Rahawaring, Rahmawati Suat, Amin Ramly. Ambon, 21, 22, 25 Juli 2013.

${ }^{25}$ Surat Keputusan Menteri Pendidikan Nasional (SK Mendiknas), No.45/U/2002, Kurikulum Inti Pendidikan Tinggi.

${ }^{26}$ Surat Keputusan Menteri Pendidikan Nasional (SK Mendiknas), No. 232/U/2000, Pedoman Penyusunan Kurikulm Pendidikan Tinggi dan Penilaian Hasil Belajar Mahasiswa. atau Pancasila, Bahasa Indonesia, Bahasa Inggris dan Pendidikan Agama. Sedangkan MKU sendiri berada di bawah pembantu rektor satu (PR 1) bidang akademik. Artinya hal-hal yang berkaitan dengan mata kuliah tersebut dikoordinasikan dengan pembantu rektor (PR) 1 di samping dengan para -pemangku kepentingan yang lain. ${ }^{27}$

Dengan demikian, mata kuliah pendidikan agama merupakan mata kuliah umum yang terdiri dari 2 SKS (sistem kredit semester) yang diberikan pada semester satu dan semester dua. Silabus disusun oleh tim yang terdiri dari para dosen, dipimpin oleh seorang koordinator yang ditunjuk universitas. Selain satu koordinator untuk mata kuliah pendidikan agama Islam, mata kuliah pendidikan agama-agama lain, seperti mata kuliah pendidikan agama Kristen, pendidikan agama Hindu, pendidikan agama Buddha, juga memiliki koordinator masingmasing. Ketua tim mata kuliah diberi otoritas untuk memantau keberlangsungan mata kuliah secara keseluruhan dengan melakukan koordinasi dengan koordinator mata kuliah MKU.

Untuk memastikan jalannya perkuliahan pendidikan agama Islam secara baik, koordinator bersama dengan para dosen agama kemudian merumuskan segala halnya yang disebut dengan garis-garis besar program pengajaran (GBPP), baik yang berkaitan dengan penyusunan materi kuliah atau format silabus, kompetensi dasar, satuan acara perkuliah (SAP), metode pengajaran, target yang hendak dicapai, indikator, sumber belajar atau

${ }^{27}$ Surat Keputusan Menteri Pendidikan Nasional (SK Mendiknas), No.45/U/2002, Kurikulum Inti Pendidikan Tinggi. 
referensi, penugasan, sistem penilaian dan kelengkapan-kelengkapan lainnya yang berhubungan dengan mata kuliah serta evaluasi di akhir-akhir semester. Segera setelah ketua koordinator dengan para dosen agama merampungkan desain mata kulian pendidikan agama Islam untuk para mahasiswa Islam, kemudian mereka melakukan pertemuan bersama dengan para tim-tim lain yang berada di bawah payung MKU. Dari situ mereka mensinergikan kira-kira apa yang perlu disamakan terkait mata kuliah masing-masing, entah itu yang berkaitan dengan materi atau silabus, metode mengajar, penugasan, evaluasi dan lain sebagainya. Hal ini dilakukan untuk memastikan perkuliahan pendidikan agama yang berada di bawah payung MKU ini berjalan dengan baik. ${ }^{28}$

Dilihat dari segi silabus, materi dan jumlah pertemuan, sesungguhnya mata kuliah pendidikan agama Islam di UNPATTI sama seperti halnya mata kuliah pendidikan agama di kampus-kampus lain. Perbedaannya paling hanya terletak pada materi yang memuat muatan lokal setiap fakultas. Artinya, mata kuliah ini materinya tidak sama persis di setiap fakultas, tetapi ada muatan-muatan lokalnya yang dimasukka di masing-masing fakultas. Misalnya, untuk Fakultas Ekonomi, ada unsur-unsur ekonomi Islam yang dimasukkan dalam materi; begitu juga di FISIP misalnya, ada unsur-unsur relasi negera dan Islam juga dimasukkan. Artinya, yang perlu ditekankan bahwa materi mata kuliah tidak kaku harus

28 Wawancara, Yunus Rahawaring, Kordinator Dosen PAI, Unpatti. Ambon, 22 Juli 2013. begini atau begitu di setiap fakultas, tetapi yang penting mengacu pada GBPP. ${ }^{29}$

Secara keseluruhan, kurang lebih ada sepuluh hingga lima belas pertemuan/tatap muka dalam setiap semester untuk mata kuliah ini. Untuk tatap muka pembahasan materi kuliah berkisar antara sepuluh pertemuan, kemudian disela dengan ujian tengah semester (UTS), review seluruh materi kuliah di akhir-akhir serta ditutup ujian akhir semester (UAS). Sedangkan sistem penilaian mahasiswa dalam mata kuliah pendidikan agama Islam berdasarkan pada empat kriteria: 1) Penilaian tertulis; 2) Penilaian melalui unjuk kerja/kinerja/ performance/keaktivan di dalam kelas; 3) Penilaian melalui sikap sehari-hari terutama ketika perkuliahan berlangsung. ${ }^{30}$

Beberapa kendala mata kuliah ini di UNPATTI di samping masih menggunakan format lama di bawah MKU sebagaimana dibahas di bagian awal sub bagian ini, juga karena beberapa hal. Pertama, minimnya jumlah mahasiswa muslim di Universitas Pattimura; kedua, pengetahuan agama mahasiswa muslim UNPATTI di bawah standar; ketiga, sistem kriedit semester yang terbatas; dan keempat, fasilitas universitas untuk mata kuliah ini terbatas.

\section{Mekanisme Rekruitmen Dosen Pendidikan Agama}

Bagian ini di samping hendak mengetahui pola rekruitment dosen di jalur formal seperti penerimaan cpns, juga hendak melihat apakah ada pola-pola lain

${ }^{29}$ Dokumen: Silabus, Satuan Acara Perkuliahan (S.A.P) Pendidikan Agama Islam, Unpatti, 2013.

${ }^{30}$ Wawancara, Amin Ramly, Dosen PAI Ambon, 22 Juli 2013. 
dalam merekruit dosen pendidikan agama, misalnya pertemanan atau karena satu aliran atau karena lainnya. Sebab seperti diketahui di sebagian tempat, jamak beberapa dosen menarik teman, kerabat dan lainnya yang satu manhaj untuk ikut mengajar di tempat dia mengajar dalam rangka memudahkan melakukan transformasi dan penyebarluasan manhaj mereka, baik di kalangan para mahasiswanya maupun di luar itu.

Berdasarkan hasil studi ini, lima dosen pendidikan agama Islam di Universitas Pattimura yang saat ini aktif mengajar, semuanya direkruit secara formal melalui penerimaan calon pegawai negeri sipil (CPNS) Kementerian Pendidikan dan Kebudayaan, dalam hal ini penerimaan CPNS dosen pendidikan agama Islam di Universitas Pattimura. Tak ada satu pun dosen yang diterima melalui jalur lain, misalnya terlebih dahulu menjadi dosen honorer, kemudian diangkat menjadi pegawai negeri sipil atau karena ajakan temannya dan pola-pola lain. Sejauh ini Universitas Pattimura memang belum pernah mendatangkan dosen honorer untuk mata kuliah pendidikan agama Islam kendati tenaga dosen pendidikan agama Islam di sana hanya satu orang dalam waktu yang sangat lama, setidaknya mulai dari universitas ini hingga tahun 2000an. Saat ini, semua dosen yang mengajar mata kuliah pendidikan agama Islam tercatat sebagai pegawai negeri sipil di Universitas Pattimura.

Menurut para dosen pendidikan agama Islam di UNPATTI, proses rekruitmen dosen pendidikan agama Islam di sana, tak ada yang berbeda dari penerimaan CPNS pada umumnya, baik di lingkungan kementerian pendidikan dan kebudayaan maupun kementerian lainnya. Sejauh berdasarkan pengalaman mereka, rekruitmen dosen agama di Universitas Pattimura paling sedikitnya melalui enam tahapan. Pertama, pihak universitas mengumumkan tentang penerimaan pegawai negeri sipil (dosen) dengan formasi dosen pendidikan agama Islam yang dibutuhkan. Pengumuman ini disebar ke publik sebagaimana layaknya penerimaan pns pada umumnya, baik itu melalui website, pengumuman di kampus, isntansi-instansi kementerian pendidikan, dan tempat-tempat lain yang bisa dijangkau oleh pelamar. ${ }^{31}$

Setelah itu masuk tahap berikutnya, tahap kedua, proses pendaftaran calon. Saat pengumuman penerimaan cpns dengan formasi dosen agama diumumkan ke publik, para calon-calon yang berminat mendaftarkan diri sesuai dengan prosedur yang telah dibuat oleh kementerian pendidikan dan kebudayaan, dalam hal ini Universitas Pattimura. Menurut para dosen, pendaftar harus memiliki kualifikasi tertentu, di mana mereka yang akan lolos seleksi berkas/administrasi adalah pendaftar yang mendapatkan gelar sarjana di perguruan tinggi Islam seperti STAIN, IAIN, UIN dan yang sejenis, baik dalam negeri maupun luar negeri. Hal itu dibuktikan, misalnya, dari ijazah-ijazah mereka yang menunjukkan bahwa mereka adalah alumni-alumni perguruan tinggi seperti yang dimaksud di atas. Dan seperti diketahui, saat ini dosen-dosen agama Islam yang mengajar di UNPATTI saat ini semuanya berlatar belakang pendidikan sarjana dari perguruan tinggi Islam seperti

31 Wawancara, Amin Ramly, Rahmawati Suat. Ambon, 21 dan 22 Juli 2013. 
dibahas di bagian komposisi sosial di bagian terdahulu.

Setelah proses kedua selesai, dan sudah banyak pendaftar yang melamar, maka masuk ke tahap ketiga, proses seleksi. Dalam proses seleksi ini, panitia penerimaan cpns terlebih dahulu mengumumkan para pendaftar yang dinyatakan lolos persyaratan berkas/administrasi. Dari situ, kemudian panitia menentukan sekaligus mengumumkan pelaksanaan test. Setelah test dilakukan, berdasarkan standar penilaian yang ditentukan oleh Kementerian Pendidikan dan Kebudayaan, panitia melakukan seleksi sesuai dengan formasi yang dibutuhkan. Jika dosen pendidikan agama Islam yang dibutuhkan di Universitas Pattimura, berjumlah satu atau dua misalnya, maka yang akan diterima oleh mereka juga hanya sesuai jumlah tersebut, tidak lebih dan tidak kurang.

Tahap keempat, pengumuman hasil. Sesudah melakukan seleksi dalam beberapa tahap, sesuai dengan prosedur dan standar mereka, maka Kementerian Pendidikan dan Kebudayaan melalui Universitas Pattimura akan mengumumkan hasil dari seleksi tersebut, siapa-siapa saja yang telah dinyatakan memenuhi kualifikasi dan diterima sebagai calon pegawai negeri sipil, dalam hal ini dosen pendidikan agama Islam di Universitas Pattimura. Berikutnya tahap kelima, proses SK dari Kementerian Pendidikan Nasional melalui Universitas Pattimura. Pada tahapan keempat, pihak panitia penerimaan cpns dosean pendidikan agama Universitas Pattimura telah mengeluarkan pengumuman tentang siapa-siapa saja yang sudah dinyatakan diterima oleh panitia. Pada tahap ini, cpns yang dinyatakan lulus tinggal menunggu
SK keluar dari Kementerian Pendidikan dan Kebudayaan melalui Universitas Pattimura. Sejauh SK belum keluar, maka yang bersangkutan belum dinyatakan sah sebagai dosen pendidikan agama Islam. Baru setelah SK dikeluarkan, maka yang bersangkutan dinyatakan sah sebagai dosen pendidikan agama Islam dan tinggal menunggu tahapan berikutnya, yaitu SK penempatan dosen.

Dan terakhir, tahap keenam, SK penempatan dosen. Tahapan ini adalah bagian akhir dari seluruh proses penerimaan pegawai negeri sipil dosen pendidikan agama di Universitas Pattimura. Setelah mengikuti tahapan-tahapan sebelumnya sampai mendapatkan SK sebagai dosen pendidikan agama yang sah, maka yang bersangkutan, dalam hal ini pns dosen yang sudah dinyatakan lulus dan mendapatkan SK dari Kemendiknas, tinggal menunggu SK penempatan dari pihak universitas. Setelah tahapan-tahapanitudilalui,makauniversitas akan mengeluarkan SK penempatan sesuai dengan fakultas atau program studi yang membutuhkannya. Jika yang membutuhkan adalah Fakultas Ekonomi, misalnya, maka yang bersangkutan akan ditempatkan di Fakultas Ekonomi. Jika tidak ditempatkan di fakultas, bisa saja pihak universitas menempatkan di tempat lain, misalnya di salah satu program studi seperti Program Studi Pendidikan Guru Sekolah Dasar (PGSD) yang dimiliki universitas. Program studi ini di Universitas Pattimura tidak berada di bawah fakultas, tetapi langsung berada di bawah rektor.

\section{Peran Lembaga Dakwah Kampus}

Beberapa kendala pendidikan agama seperti di atas, sedikit teratasi dengan peran 
lembagadakwahkampus(LDK)yangmendata dan memberikan bimbingan terhadap para mahasiswa muslim di Unversitas Pattimura. Peran LDK ini di samping sebagai tugas pokok dan fungsi utama mereka sebagai lembaga yang tergabung dalam unit kegiatan mahasiswa di bawah rektorat, juga memang sengaja diminta oleh dosen-dosen agama untuk membantu proses keberlangsungan mata kuliah agama di Universitas Pattimura, baik dari sesi materi kuliah, pembinaan, maupun pelibatan dalam kegiatan-kegiatan mereka. ${ }^{32}$

Namun demikian, perlu diakui bahwa LDK sumber dayanya terbatas, tidak bisa mengatasi semua kendala yang dialami oleh mata kuliah pendidikan agama Islam. Akan tetapi kendati tidak bisa memegang dan menyelesaikan semua kendala yang ada, tetapi LDK cukup memberikan kontribusi besar dalam mengurangi berbagai masalah yang ada. Dalam bentuk apakah kontribusi LDK dalam mebantu mata kuliah pendidikan agama Islam? Sejauh hasil pengamatan dan wawancara studi ini, ada beberapa tahap yang dilakukan oleh LDK dalam membantu meningkatkan kemampuan pengetahuan dan kualitas keagamaan para mahasiswa muslim. Tahapan program itu berada di bawah satu payung program yang bernama 'mentoring. ${ }^{33}$

Mentoring ini kegiatannya beragam. Dalam menjalankan program ini, pertamapertama, LDK melakukan peNdataan terhadap seluruh mahasiswa muslim di tingkat universitas. Setelah itu mereka

${ }^{32}$ Dokumen statuta, AD/ART, Lembaga Dakwah Kampus "Al-Ikhwan" Unpatti. Ambon, 2012.

${ }^{33}$ Wawancara Afif, Ketua LDK Il-Ikhwan. Ambon, 22 Juli 2013. mendata di tingkat fakultas dan dipastikan tidak satu pun mahasiswa muslim yang tidak terdata. Pendataan ini dilakukan ketika pengumuman kelulusan dan menjelang dilaksanakannya orientasi pengenalan kampus (ospek) untuk mahasiswa baru. Setelah mendapatkan jumlah mahasiswa muslim tingkat universitas dan tingkat fakultas, lalu dibuat pengelompokan dan dibagi berdasar fakultas masing-masing. Ini dilakukan untuk memudahkan proses mentoring, karena pelaksanaan mentoring diserahkan kepada lembaga dakwah fakultas dengan dikoordinasikan, dipantau, dan disupervisi oleh lembaga dakwah tingkat universitas. Di tingkat fakultaslah mereka (LDK dan LDF) melakukan mentoring dengan terlebih dahulu mengetes kemampuan membaca Al-Qur'an para mahasiswa baru. Bila bacaan Al-Qur'annya belum bagus, maka mereka terlebih dahulu memberikan materi belajar Al-Qur'an hingga fasih. Akan tetapi jika bacaan Al-Qur'annya bagus, maka para seniiornya memberikan materi mentoring lanjutan dengan menggunakan diktat mentoring yang telah disiapkan oleh LDK tingkat provinsi dan nasional. ${ }^{34}$

Dalam konteks ini, peran LDK tentu saja sangat kontributif terhadap keberlangsungan mata kuliah pendidikan agama Islam karena mereka bisa mengisi ruang kosong yang ditinggal oleh mata kuliah tersebut. Akan tetapi juga ada sisi kelemahannya jika tanpa pengawasan yang ketat dari para koordinator dan dosen agama. Kelemahannya terletak pada kemungkinan adanya penyimpangan oleh

34 Wawancara, Afif (Ketua LDK Il-Ikhwan), Rahman, La Ode Amin (pengurus LDK). Ambon, 22, 24 Juli 2013. 
para mentor-mentor mereka, terutama dalam melakukan transfer ilmu, misalnya ke pemahaman yang radikal. Karena seperti diketahui, dalam proses mentoring, mentor juga ikut menentukan apakah materi yang disampaikan akan digiring ke pola-pola pengajaran yang radikal atau moderat. Karena kalaupun materi kuliahnya tak ada yang radikal, akan tetapi jika mentor memiliki kecenderungan radikal, maka materi-materi tersebut bisa diseret pada pemahaman-pemahaman yang memiliki kecenderungan radikal pula. Kekhawatiran seperti ini tidak sempat diteliti lebih lanjut dalam penelitian ini.

\section{PENUTUP}

Berpijak dari uraian di atas, penelitian ini menyimpulkan beberapa hal berikut. Pertama, mata kuliah agama di UNPATTI masih termasuk dalam kategori mata kuliah umum (MKU). Ini berarti belum merujuk pada keputusan menteri pendidikan dan kebudayaan 232 tahun 2002, menjadi mata kuliah pengembangan kepribadian (MPK), tidak pula mengikuti undang-undang perguruan tinggi nomor 12 tahun 2012 dibawah payung mata kuliah wajib umum (MKWU). Khusus desain operasional, berdasarkan GBPP mata kuliah pendidikan agama Islam, mengikuti Standar Kurikulum Nasional, termasuk juga kapasitas dosennya yang memiliki kualifikasi Strata 2, dan Strata 3. Kendala mata kuliah ini terletak pada rendahnya pengetahuan agama mahasiswa muslim, sedikitnya jumlah SKS, serta fasilitas perkuliahan yang belum memadai.

Kedua, rekruitmen dosen mata kuliah agama Islam di UNPATTI berjalan secara fair. Dugaan tentang adanya penerimaan dosen agama di luar jalur formal (misalnya karena pertemanan atau karena satu aliran, memiliki pemahaman keagamaan yang sama), tidak ditemukan di lapangan. Semua dosen pendidikan agama Islam di Universitas Pattimura mengikuti proses seleksi penerimaan pegawai negeri sipil yang diselenggarakan oleh Kementerian Pendidikan dan Kebudayaan, melalui Universitas Pattimura.

Ketiga, lembaga dakwah kampus (LDK) memberikan kontribusi besar dalam mengatasi kendala-kendala tersebut, meskipun belum maksimal karena berbagai kendala teknis. Salah satu kendala yang dihadapi oleh LDK Al-Ikhwan Unpati adalah stigma sebagai organisasi mahasiswa keagamaan yang berada di kampus yang dicurigai mengajarkan ajaran radikal. LDK Al-Ikhwan berada dalam bimbingan dan kordinasi para dosen Pendidikan agama Islam. Pembantu rektor tiga juga turut terlibat dalam pembinaan LDK Al-Ikhwan.

Keempat, karena berbagai keterbatasan yang dimilikinya, maka peran pendidikan agama masih belum maksimal dalam merajut keutuhan masyarakat kampus, khususnya mahasiswa. Segregasi masyarakat Ambon berdasarkan agama, masih belum dapat dijembatani secara sistematis di dalam kampus. Beberapa event yang menyatukan berbagai golongan dan agama yang diselenggarakan di kampus dimotori langsung oleh pimpinan perguruan tinggi, dan kurang menunjukkan fungsi pendidikan agama atau organisasi agama di kampus.

Untuk memperbaiki hal tersebut, perlu dilkakukan beberapa hal berikut. Pertama, perubahan payung mata kuliah agama dari mata kuliah umum (MKU) ke mata kuliah 
pengembangan kepribadian (MPK) dan sekarang menjadi matakuliah wajib umum (MKWU). Kedua, jika proses perubahan tersebut berhasil, maka dosen perlu peningkatan mutu dengan memperkenalkan pendidikan karakter, dan wawasan keilmuan sesuai dengan rumpun fakultas atau jurusan yang diampuh. Dosen agama tidak hanya mendalami dan menguasai pengetahuan agama secara sempit, tetapi juga korelasinya terhadap sains. Ketiga, pendidikan agama di tingkat sekolah menengah atas perlu dievaluasi dan diperbaiki sehingga ketika para siswa memasuki dunia perguruan tinggi, sudah bisa beradaptasi dengan materi-materi agama tingkat lanjut. Keempat, koordinasi dan komunikasi dengan LDK harus intensif untuk menjaga eksistensi lembaga mahasiswa ini dari jaringan kelompok-kelompok radikal.

\section{UCAPAN TERIMA KASIH}

Atas selesainya artikel ini saya merasa perlu menyampaikan terima kasih kepada beberapa orang dan pihak-pihak yang telah mendukung, antara lain: jajaran kampus universitas Patimura (Unpati) yang telah memberikan data dan informasi yang dibutuhkan; pengurus lembaga dakwah kampus (LDK) Al-Ikhwan Unpati; dan para responden terutama dosen PAI Unpati. Kepada saudara Muhammad Nabil yang telah membantu dalam pengumpulan data dan penulisan laporan penelitian. Terakhir, terima kasih yang tak terhingga saya sampaikan kepada Pusat Penelitian dan Pengembangan Pendidikan Agama dan Keagamaan (Puslitbang Penda) yang telah mendanai penelitian ini.

\section{DAFTAR PUSTAKA}

DIKTI (tanpa tahun): Panduan pembelajaran Pendidikan agama Islam (PAI) di Perguruan Tinggi. Jakarta: Dirjen Dikti.

Hieriej, Eddy O.S. ed. (tanpa tahun): Format Ulang Birokrasi kota Ambon. Ambon: Batukar Info.

Kholidah, Lilik Nur (2010): Implementasi strategi pembelajaran mata kuliah pendidikan agama Islam pada Perguruan Tinggi Negeri di Surabaya, Disertasi, Universitas Negeri Malang.

LDK Al-Ikhwan (2012): Dokumen statuta, AD/ART, Lembaga Dakwah Kampus "AlIkhwan" Unpatti. Ambon.

Munip, Abdul (2008): Perkuliahan pendidikan agama Islam di perguruan tinggi negeri (sebuah catatan lapangan), Jurnal Pendidikan Agama Islam Vol. V, No, 1.

Murdiono, Mukhammad. (tanpa tahun): Strategi Internalisasi Nilai Moral Religius Dalam Proses Pembelajaran di Perguruan Tinggi, Jurnal Cakrawal Pendidikan, LPM UNY.

Novitasari, Suko Wiyono. (tanpa tahun): Penerapan Otonomi Perguruan Tinggi Untuk Menunjang Pelaksanaan Tridharma Di Jurusan Hukum Dan Kewarganegaraan Fakultas Ilmu Sosial Universitas Negeri Malang.

PP nomor 55 tahun 2007, tentang Pendidikan Agama dan Keagamaan.

Rahawarin, Yunus (2013): Kerja sama antar umat beragama: Studi Rekonsiliasi Konflik Agama di Maluku dan Tual. Vol. VII, nomor 1.

Siregar, Imran (2014): Model Pengajaran Agama Islam Di Universitas Sumatera Utara (USU) Medan, Jurnal AL-Qalam, Makassar, vol. 20. Nomor 1. 
SK Dirjen DIKTI DIKNAS nomor 43 / DIKTI / Kep / 2006, tentang: Rambu-rambu Pelaksanaan Kelompok Matakuliah Pengembangan Kepribadian di Perguruan Tinggi.

Surat Keputusan Menteri Pendidikan Nasional (SK Mendiknas), No. 232/U/2000, Pedoman Penyusunan Kurikulm Pendidikan Tinggi dan Penilaian Hasil Belajar Mahasiswa.

Surat Keputusan Menteri Pendidikan Nasional(SKMendiknas),No.45/U/2002, Kurikulum Inti Pendidikan Tinggi.

Undang-undang nomor 12 tahun 2012, tentang Pendidikan Tinggi.

Universitas Pattimura. 2011. Buku Profil Akademik Universitas Pattimura, Ambon..

Universitas Pattimura. 2011. Dokumen: Silabus, Satuan Acara Perkuliahan (S.A.P) Pendidikan Agama Islam, Ambon: Unpatti.

UU nomor 2 tahun 1989, tentang sistem pendidikan nasional.

UU nomor 20 tahun 2003, tentang sistem pendidikan nasional.

\section{Internet}

http://www.batukarinfo.com/system/ files/Ambon\%20SKJ\%20Lengkap.pdf.

http://jurnal-online.um.ac.id/data/artikel/ artikel85CB89239345E974CBDF4A66273 3E490.pdf.

http://kuliahdaring.dikti.go.id/lms1/ pluginfile.php/14028/mod_ resource/content/4/PANDUAN\%20 PEMBELAJARAN\%20PAI.pdf.
http://id.wikipedia.org/wiki/Universitas_ Pattimura.

http://www.unpatti.com/visi_misi_ unpatti_ambon.html.

https://www.reference.com/world-view/ religious-education-importantaa58f6bbce7b79e0.

\section{Informan}

Abdul Kahar. Widya Iswara Balai Diklat Ambon, Wawancara di kota Ambon, 21, 23, 25, Juli 2013.

Adriani Banjar, Pembantu Rektor Tiga Unpatti, Wawanara di kota Ambon, 24 Juli 2013.

Amin Ramly, Dosen Pendidikan Agama Islam Unpatti, Wawancara di kota Ambon, tanggal: 21, 22, 25 Juli 2013.

Atikah Kharunnisa, Dosen Pendidikan Agama Islam Unpatti, Wawancara di kota Ambon, tanggal: 21, 22, 25 Juli 2013.

La Ode Amin, Pengurus LDK Il-Ikhwan Unpatti, Wawancara di kota Ambon, 22 dan 24 Juli 2013.

Muahammad Afif, Ketua LDK Il-Ikhwan Unpatti, Wawancara di kota Ambon, 22 dan 24 Juli 2013.

Rahman, Pengurus LDK Il-Ikhwan Unpatti, Wawancara di kota Ambon, 22 dan 24 Juli 2013.

Rahmawati Suat, Dosen Pendidikan Agama Islam Unpatti, Wawancara di kota Ambon, tanggal: 21, 22, 25 Juli 2013.

Yunus Rahawaring, Dosen Pendidikan Agama Islam Unpatti, Wawancara di kota Ambon, tanggal: 21, 22, 25 Juli 2013. 